УДК 005.96:005.591.6-044.52.

DOI: $10.15673 /$ fie.v12i1.1668

Козак К.Б.

кандидат економічних наук, доцент кафедра менеджменту та логістики E-mail: kozakkate.coach@gmail.com

ORCID ID: 0000-0002-8099-6607
Корсікова Н.М.

кандидат економічних наук, доцент кафедра менеджменту та логістики

E-mail:nkorsikova@ukr.net

ORCID ID: 0000-0002-1649-4725

Древова В.В.

студентка 4 курсу фракультету менеджменту, маркетингу та логістики

Одеська національна академія харчових технологій

вул. Канатна 112, м. Одеса, Україна, 65039

E-mail: prost0.vika1409@gmail.com

ORCID ID: 0000-0002-7278-5105

\title{
ТИПОЛОГІЯ КОНФЛІКТНИХ ОСОБИСТОСТЕЙ ТА АЛГОРИТМ ВЗАЄМОДІї З НИМИ В РОБОЧОМУ ПРОЦЕСІ
}

У такого складного феномена, яким є конфллікт, є безліч джерел, що криються в самій природі людини. Дана стаття присвячена дослідженню класифікації конфліктних особистостей та стратегій спілкування з ними для попередження виникнення конфліктних ситуацій під час управління персоналом та, взагалі, робочого процесу. У статті виявлені стратегії взаємодії з конфоліктними особистостями, враховуючи їх поведінкові характеристики відповідно кожного типу. Також ми приділили увагу такому важливому фактору, як відмінність темпераменту та характеру особистостей, що впливає на взаємодію людей під час співпраці. Наприкінці статті сформований універсальний алгоритм вирішення трудових конфліктів, використання якого дозволить уникнути руйнівних наслідків деструктивних конфліктів в робочому процесі.

Ключові слова: конфлікт, конфліктність, конфрліктна ситуація, конфрліктна особистість, демонстративний тип, ригідний тип, некерований тип, надточний тип, безконфліктний тип, раціональний тип, «важкі» люди.

This work is licensed under a Creative Commons Attribution 4.0 International License http://creativecommons.org/licenses/by/4.0/

Постановка проблеми та зв'язок з важливими науковими та практичними завданнями. Як показує практика вирішення конфліктів, конфліктних особистостей в колективах не так вже й багато - від одного до трьох відсотків від числа працюючих в організації. Але кількість створюваних ними конфліктів значна, причому конфліктів затяжних. Необхідність працювати і спілкуватися з конфліктною особистістю може перетворити життя на «справжнє пекло». Чимало експертів щодо організаційної поведінки присвятили час вивченню природи конфліктогенності людей, деякі з них виявили закономірності поведінки та класифікували їх за рівнями конфліктності.

Типології конфліктних осіб дозволяють вивести універсальні стратегії спілкування 3 такими людьми в робочому процесі, а це важливо, насамперед, для керівників під час управління персоналом. Робота багатьох сучасних психологів та конфліктологів в основному зосереджена на дослідженні соціобіологічних мотиваторів осіб, схильних до конфліктів, 3 метою запобігання конфліктних ситуацій на роботі та в побуті. У зв'язку з актуальністю та притаманністю відповідних проблем для широкого кола та сфер діяльності, у 2013 році в Україні було створено незалежний некомерційний центр 3 аналізу соціаль- но-економічних проблем, колективних протестів, трудових відносин і конфліктів (Центр соціальних і трудових досліджень, ЦСТД) [1]. Але питання і надалі залишається не тільки невирішеним, а й і загострюється в умовах швидкозмінного та невизначеного середовища [2].

Аналіз останніх публікацій по проблемі. Проблемою схильності людини до конфліктів займалися ще здавна: китайський філософ Сунь-цзи, теоретик Середньовіччя Н. Макіавеллі, 3. Фрейд визначали агресивність людської сутності. Поясненню конфліктогенності особистості присвятили чимало робіт такі відомі дослідники, як Г. Зіммель, К. Лоренц, У. Макдугалл, К. Хорні, А. Адлер, Е. Фромм, К. Левін, Д. Доллард, В. П. Захаров,Ю. О. Симоненко, видатні психологи Є. С. Романова, Л. Р. Гребенніков, В. Шейнов, Р. Бремсон, Е. Берн та багато інших відомих дослідників.

Цікавість для нашого дослідження представляють типології конфліктних особистостей за С. М.Смельяновим, Дж. Г. Скоттом, Ф. М. Бородкіним та Н. М. Коряком.

Свої теоретичні дослідження активно використовують в практичній діяльності відомі вітчизняні експерти-конфліктологи К. Козак, Ю. Верста, 


\section{А. Гусєв, С. Калаур, інші.}

Формулювання цілей дослідження. Метою даного дослідження являється вивчення природи конфліктогенної особистості на основі наукових досягнень зарубіжних та вітчизняних вчених, розгляд особливостей класифікацій конфліктних особистостей за ознакою впливу не зовнішніх чинників, а саме психологічних факторів людини, та виявлення стратегій поведінки з такими особами задля попередження виникнення конфліктних ситуацій в робочому процесі.

Виклад основних результатів та їх обгрунтування. У такого складного феномена, яким є конфлікт, є безліч джерел, що криються в самій природі людини.

Дійсно, ще в III столітті до н. е. великий китайський філософ Сунь-цзи вказував на «злу природу» людини. Відомий теоретик Середньовіччя Н. Макіавеллі бачив причину конфліктів в «порочності самої природи людини», а Ч. Дарвін і його послідовники - в боротьбі за існування.

За 3. Фрейдом, людина має конфліктну природу, оскільки в конфліктному протистоянні знаходяться глибинні шари його психіки, в самій людині $\epsilon$ в наявності схильність до агресії і початкова ворожість до інших людей [3].

На існування у людей інстинкту ворожості вказував Г. Зіммель, агресивності - К. Лоренц, «забіякуватості» - У. Макдугалл, нестачі доброзичливості К. Хорні. А. Адлер бачив причину конфліктів в спробах людини звільнитися від комплексу неповноцінності і домінування над ним, К. Левін - в порушенні рівноваги між індивідом і середовищем, Д. Доллард - у дезорганізації свідомості та діяльності і агресії.

Цей огляд суджень серйозних дослідників наводить на такі, аж ніяк не милостиві думки: поширеність конфліктів в людському суспільстві - суть прояву конфліктної природи людини; а коли так, то конфліктуючим слід шукати причини конфліктів не тільки в діях опонентів, а й в самих собі. Конфліктною називається особистість, яка в силу певних своїх властивостей $\epsilon$ ініціатором багатьох негативних i/aбо деструктивних конфліктів, а також володіє схильністю долучатися до конфліктів, які створені іншими [4].

Як уже зазначалося, конфліктність закладена в природі людини. Для нас найважливіше знайти способи прогнозування конфліктних ситуацій і конфліктів, що визначаються рисами характеру окремих особистостей. Для діагностики конфлікту i, зокрема, причин його виникнення, необхідно знати, які специфічні особистісні характеристики можуть виявитися суб'єктивними передумовами конфлікту. Знання ступеню конфліктності/неконфліктності особистості допоможе проникнути в суб'єктивні умови виникнення конфлікту.

Так, типи конфліктних особистостей варто розбити на два різновиди: ситуативно-конфліктні і перманентно-конфліктні.

Для першого різновиду людей конфліктність - це не властивість характеру, а реакція на конкретну ситуацію. Їх готовність в окремих випадках йти на конфлікт викликається відсутністю іншого виходу 3 конфліктної ситуації.

Другий різновид людей - індивіди, для яких конфліктність - постійна властивість власного характеру і поведінки (рис. 1).



Рис. 1. Поведінкова характеристика в цілому конфліктних людей* *авторська розробка 
3 усіх класифікацій цього різновиду найбільш вдалою, на нашу думку, виявилася запропонована Ф. М. Бородкіним і Н. М. Коряком [5]. Зазначені автори виділили шість типів конфліктних особистостей, що провокують або посилюють конфліктні відносини (табл.1).

Таблиця 1

Типологія конфліктних особистостей за Ф. М. Бородкіним та Н. М. Коряком*

\begin{tabular}{|c|c|}
\hline обистості & Поведінкові характеристики \\
\hline Демонстративний & $\begin{array}{l}\text { 1. Бажає знаходитись завжди в центрі уваги. } \\
\text { 2. Любить добре виглядати в очах інших. } \\
\text { 3. Його ставлення до людей визначається тим, як ставляться до нього. } \\
\text { 4. Він відчуває себе впевнено при неглибоких конфліктах. } \\
\text { 5. Добре пристосовується до різних ситуацій. } \\
\text { 6. Раціональна поведінка виражена слабко, поведінка виключно емоційна. } \\
\text { 7. Планування своєї діяльності здійснює епізодично. } \\
\text { 8. Уникає копіткої, систематичної роботи. } \\
\text { 9. Не ухиляється від конфліктів, але в ситуації спору відчуває себе погано. } \\
\text { 10. Часто виявляється «джерелом» суперечок, але не вважає себе таким. } \\
\text { Навіть при відсутності будь-яких підстав може піти на конфлікт, щоб хоч таким чином } \\
\text { бути на виду. }\end{array}$ \\
\hline $\begin{array}{l}\text { Ригідний (слово } \\
\text { «ригідний» озна- } \\
\text { чає негнучкий, } \\
\text { непластичний) }\end{array}$ & $\begin{array}{l}\text { 1. Підозрілий. } \\
\text { 2. Володіє завищеною самооцінкою. } \\
\text { 3. Постійно вимагає підтверджень власної значущості. } \\
\text { 4. Слабко реагує на зміни ситуації і обставин. } \\
\text { 5. Прямолінійний і негнучкий. } \\
\text { 6. } 3 \text { великими труднощами приймає до уваги точку зору оточуючих, мало зважає на } \\
\text { їхню думку. } \\
\text { 7. Завжди очікує прояву поваги з боку оточуючих. } \\
\text { 8. Вираз недоброзичливості з боку оточуючих сприймаються їм з образою. } \\
\text { 9. Некритичний по відношенню до своїх вчинків. } \\
\text { 10. Болісно уразливий, підвищено чутливий по відношенню до дійсних або уявних не- } \\
\text { справедливостей. } \\
\text { Раз і назавжди сформована думка ригидної особистості неминуче приходить в супере- } \\
\text { чність з умовами, що змінюються і викликає конфлікт з оточуючими. Це ті люди, чиїм } \\
\text { життєвим кредо є установка «якщо факти нас не влаштовують, тим гірше для фактів». } \\
\text { Поведінка відрізняється безцеремонністю, що перетікає в грубість. }\end{array}$ \\
\hline Некерований & $\begin{array}{l}\text { 1. Імпульсивний, недостатньо контролює себе. } \\
\text { 2. Його поведінка важко передбачувана. } \\
\text { 3. Поводиться зухвало, агресивно. } \\
\text { 4. Часто порушує загальноприйняті норми. } \\
\text { 5. Володіє завищеною самооцінкою. } \\
\text { 6. Постійно вимагає підтвердження власної значущості. } \\
\text { 7. У невдачах, неприємностях схильний звинувачувати інших. } \\
\text { 8. Не може грамотно спланувати свою діяльність і втілювати плани в життя. } \\
\text { 9. Погано співвідносить свої вчинки з цілями і обставинами. } \\
\text { 10. } 3 \text { минулого досвіду (навіть гіркого) не робить належних висновків. }\end{array}$ \\
\hline Надточний & $\begin{array}{l}\text { 1. Прискіпливо ставиться до роботи. } \\
\text { 2. Висуває підвищені вимоги до себе. } \\
\text { 3. Висуває підвищені вимоги до оточуючих, причому робить це так, що людям, які з } \\
\text { ним працюють, здавалось, що він чіпляється. } \\
\text { 4. Володіє підвищеною тривожністю. } \\
\text { 5. Надмірно чутливий до деталей. } \\
\text { 6. Болісно реагує на зауваження оточуючих. } \\
\text { 7. Може порвати відносини з друзями, знайомими через уявні образи. } \\
\text { 8. Страждає, переживаючи свої прорахунки, невдачі, розплачуючись за них хворобами } \\
\text { (безсонням, головними болями і т.д.). } \\
\text { 9. Стриманий у зовнішніх, особливо емоційних, проявах. } \\
\text { 10. Неадекватно оцінює реальні взаємини в групі. } \\
\text { Всі ці особливості нерідко призводять до невлаштованості особистого життя. }\end{array}$ \\
\hline
\end{tabular}




\begin{tabular}{|c|c|}
\hline & н табл. \\
\hline Тип особистості & Поведінкові характеристики \\
\hline Безконфліктний & $\begin{array}{l}\text { 1. Нестійкий в оцінках і думках. } \\
\text { 2. Легко піддається навіюванню. } \\
\text { 3. Внутрішньо суперечливий. } \\
\text { 4. Відрізняється деякою непослідовністю поведінки. } \\
\text { 5. Орієнтується на миттєвий успіх. } \\
\text { 6. Не вміє бачити перспективу. } \\
\text { 7. Залежить від думки оточуючих, особливо лідерів. } \\
\text { 8. Завжди прагне до компромісу. } \\
\text { 9. Не має силу волі. } \\
\text { 10. Не замислюється над наслідками своїх вчинків і причинами вчинків оточуючих. } \\
\text { Відсутність власних переконань і принципів може зробити безконфліктну людину зна- } \\
\text { ряддям в руках особи, під впливом якої він опинився. Небезпека, яку представляють } \\
\text { люди цього типу, полягає в тому, що найчастіше вони мають репутацію добрих людей, } \\
\text { від яких не чекають ніякого підступу. Тому виступ такої людини як ініціатора конфлік- } \\
\text { ту сприймається колективом як об'єктивний і неупереджений. } \\
\text { На відміну від перших чотирьох типів цей тип (майже як і попередній) є «ситуатив- } \\
\text { ним», тобто проявляється тільки при виникненні певної ситуації. В даному випадку - це } \\
\text { наявність цілеспрямованого негативного впливу на таку людину. Представники всіх } \\
\text { інших типів вступають в конфлікт з власної ініціативи. }\end{array}$ \\
\hline $\begin{array}{l}\text { Цілеспрямовано } \\
\text { конфліктний (ра- } \\
\text { ціональний) }\end{array}$ & $\begin{array}{l}\text { 1. Розглядає конфлікт як засіб досягнення власних цілей. } \\
\text { 2. Часто виступає активною стороною в розв'язанні конфліктів. } \\
\text { 3. Схильний до маніпуляцій у взаєминах. } \\
\text { 4. У конфлікті діє раціонально, прораховує варіанти, оцінює сили і позиції сторін. } \\
\text { 5. Володіє добре відпрацьованою технікою спілкування в гарячій суперечці. } \\
\text { Довгий час може виконувати роль беззаперечного підлеглого, наприклад, до тих пір, } \\
\text { поки не «захитається крісло» під начальником. Тут-то раціоналіст і проявить себе, пе- } \\
\text { ршим зрадивши керівника. }\end{array}$ \\
\hline
\end{tabular}

* Систематизовано авторами на підставі джерел [5]

Для «демонстративних», «ригідних», «некерованих» $\mathrm{i}$ «надточних» особистостей прояви конфліктної поведінки швидше деструктивне явище, але таким є психологічний склад. Цікаво відмітити, деякі експерти 3 питань психології та управління трудовими ресурсами визначають, що більшість 3 них страждає різними комплексами, зокрема комплексом неповноцінності, що може негативно впливати на трудову мотивацію, власну ефективність, зацікавленість у робочому процесі.
Детальний аналіз різних типів конфліктних особистостей, а також інструментів взаємодії з ними пропонує в своїх роботах Дж. Г. Скотт [7]. Так, систематизуючи типологію конфліктних особистостей та істотно допонюючи їі , Скотт Дж. Г. спирається на дані, які запропонував Р. М. Бремсон [8] у книзі «Спілкування з важкими людьми». Розглянемо детальніше типи важких у спілкуванні людей та стратегії поведінки $з$ ними (табл.2), а саме тип конфліктної особистості, поведінкові характеристики та відповідні стратегії спілкування.

Таблиця 2

Типологія «важких» людей за Дж. Г. Скоттом та стратегії поведінки $з$ ними*

\begin{tabular}{|c|c|c|}
\hline Тип & Поведінкові характеристики & Стратегії спілкування \\
\hline $\begin{array}{l}\text { «паровий каток» / } \\
\text { «шерманівській } \\
\text { танк» }\end{array}$ & $\begin{array}{l}\text { Це грубі і безцеремонні люди, які } \\
\text { вважають, що всі повинні розступати- } \\
\text { ся перед ними. Вони переконані в } \\
\text { своїй абсолютній правоті і хочуть, } \\
\text { щоб всі оточуючі про неї знали }\end{array}$ & $\begin{array}{l}\text { Якщо предмет конфлікту для вас не особливо } \\
\text { важливий, то краще від нього відхилитися, як- } \\
\text { що ж ви вирішили прийняти бій, то краще поча- } \\
\text { ти } 3 \text { того, щоб дати такій людині можливість } \\
\text { «випустити пару», а потім спокійно виказати } \\
\text { свою точку зору. Але при цьому визначте свою } \\
\text { роль як роль миротворця, що стоїть над конфлі- } \\
\text { ктом. Подавіть їі лють і агресивність своїм спо- } \\
\text { коєм }\end{array}$ \\
\hline
\end{tabular}


Продовження табл. 2

\begin{tabular}{|c|c|c|}
\hline Тип & Поведінкові характеристики & Стратегії спілкування \\
\hline $\begin{array}{l}\text { «прихований агре- } \\
\text { сор» / «снайпер» }\end{array}$ & $\begin{array}{l}\text { Така людина прагне робити людям } \\
\text { неприємності за допомогою махіна- } \\
\text { цій, інтриг, пліток. Вона вважає, що } \\
\text { така їі поведінка повністю виправда- } \\
\text { на: хтось інший вчинив неправильно, } \\
\text { а вона бере на себе місію таємного } \\
\text { месника. Інша причина такої поведін- } \\
\text { ки - нестача владних ресурсів для } \\
\text { проведення відкритих дій }\end{array}$ & $\begin{array}{l}\text { Виявити конкретний факт спричинення зла i } \\
\text { його приховані причини, дати зрозуміти атаку- } \\
\text { ючій людині, що ви вищі за це, сказавши що- } \\
\text { небудь на зразок: «Чого ви добиваєтеся цим?». } \\
\text { При цьому зберігати спокій, щоб не спровоку- } \\
\text { вати відкритого зіткнення }\end{array}$ \\
\hline $\begin{array}{l}\text { «розгнівана дити- } \\
\text { на» / «вибухова } \\
\text { людина» }\end{array}$ & $\begin{array}{l}\text { Людина цього типу не є злою за при- } \\
\text { родою, але вона «вибухає» як дитина, } \\
\text { у якої поганий настрій. Звичайно, } \\
\text { причина такої поведінки - страх, без- } \\
\text { порадність, а вибух емоцій демон- } \\
\text { струє бажання взяти ситуацію під } \\
\text { контроль }\end{array}$ & $\begin{array}{l}\text { Дати людині накричатися, дати вихід її емоці- } \\
\text { ям, переконати її у тому, що ви ії слухаєте, що } \\
\text { вона контролює ситуацію, і тим самим заспоко- } \\
\text { їти їі. Після цього дипломатично і доброзичли- } \\
\text { во запропонувати ій обговорити проблему, що } \\
\text { виникла }\end{array}$ \\
\hline «скаржник» & $\begin{array}{l}\text { У деяких випадках можна зіткнутися } \\
3 \text { даним типом людей як слухач, в } \\
\text { інших - як предмет їхніх скарг і зви- } \\
\text { нувачень }\end{array}$ & $\begin{array}{l}\text { Вислухайте людину незалежно від того, має } \\
\text { рацію вона або не має рації, тим самим ви пове- } \\
\text { рнете їй відчуття власної значущості. Потім, } \\
\text { після вислову суті його основної скарги, нео-- } \\
\text { хідно шукати спосіб припинення розмови або } \\
\text { переведення ії на іншу тему. Також рекоменду- } \\
\text { ється привернути її увагу на вирішення пробле- } \\
\text { ми, з'ясувати, що вона збирається робити, які } \\
\text { способи вирішення проблеми бачить }\end{array}$ \\
\hline $\begin{array}{l}\text { «мовчун» / «тихо- } \\
\text { ня» }\end{array}$ & $\begin{array}{l}\text { Люди цього типу можуть бути скрит- } \\
\text { ними } 3 \text { різних причин, причому при- } \\
\text { чини цієї скритності вам невідомі. } \\
\text { Ключ до вирішення конфлікту в даній } \\
\text { ситуації - подолання цієї замкнутості }\end{array}$ & $\begin{array}{l}\text { Поставити декілька питань, але обов'язково в } \\
\text { такій формі, щоб не одержати на них односкла- } \\
\text { дові відповіді, продемонструвати своє співчут- } \\
\text { ливе і доброзичливе ставлення до даної люди- } \\
\text { ни, свою підтримку і визнання }\end{array}$ \\
\hline «надпоступливий» & $\begin{array}{l}\text { Вони завжди і у всьому поступаються } \\
\text { іншим людям, і на перший погляд, не } \\
\text { створюють особливих труднощів у } \\
\text { процесі взаємодії, але тільки на пер- } \\
\text { ший. Час від часу вони створюють } \\
\text { проблеми: ви у всьому покладаєтеся } \\
\text { на людину, а потім виявляється, що її } \\
\text { слова розходяться зі справою }\end{array}$ & $\begin{array}{l}\text { Показати людині цього типу, що ви хочете пра- } \\
\text { вдивості з їі сторони, постаратися переконати ії } \\
\text { у тому, що ваше ставлення до неї визначати- } \\
\text { меться не тим, що вона у всьому з вами пого- } \\
\text { джується, а тим, наскільки вона буде правдива, i } \\
\text { наскільки послідовно вона діятиме надалі }\end{array}$ \\
\hline
\end{tabular}

* Систематизовано авторами на підставі джерел $[7,8,9,10,11]$

До цих основних типів «важких» людей додаються ще безліч інших (рис. 2).

Варто також додати, що на поведінку учасників конфліктів значний вплив мають відмінності в типах цих людей. Це необхідно брати до уваги при роботі в умовах конфлікту. О. Крегер і Дж. Тьюсон вважають, що особливості характеру людей лежать в основі їх взаємодії; не враховуючи ці особливості, неможливо вирішити жоден конфлікт [12]. У разі виникнення конфліктної проблеми необхідно визначити, чи належать потенційні учасники конфлікту до розряду «важких» людей, і відповідно будувати своє спілкування з ними.

Розглянемо деякі загальні поради стосовно поведінки з основними типами конфліктних особистостей в колективі заради попередження конфліктних ситуацій [12]:

1. Демонстративний тип. Керівникам і колегам слід частіше робити їм компліменти - за принци- пом: «Краще підіграти в малому, ніж потім розплачуватися $з$ потенційним ворогом, помсти за відсутність знаків уваги».

2. Ригідний тип. Керівникам і колегам краще поводитись 3 такими людьми так, щоб не провокувати зайві образи і підозри. Таким співробітникам краще не доручати роботи, пов'язані 3 гнучкою поведінкою.

3. Некерований тип. У спілкуванні з такими працівниками слід пам'ятати, що насправді вони передбачувані, оскільки їх «неконтрольованість» часто повторюється. Тому, якщо вивчити типові реакції таких людей, можна фактично керувати ними, використовуючи навіть у вирішенні низки ділових питань (наприклад, брати таких запальних співробітників на ті переговори, де багато вирішується за допомогою емоцій, а не розуму). На жаль, «управління» поведінкою таких працівників походить на маніпуляцію. 


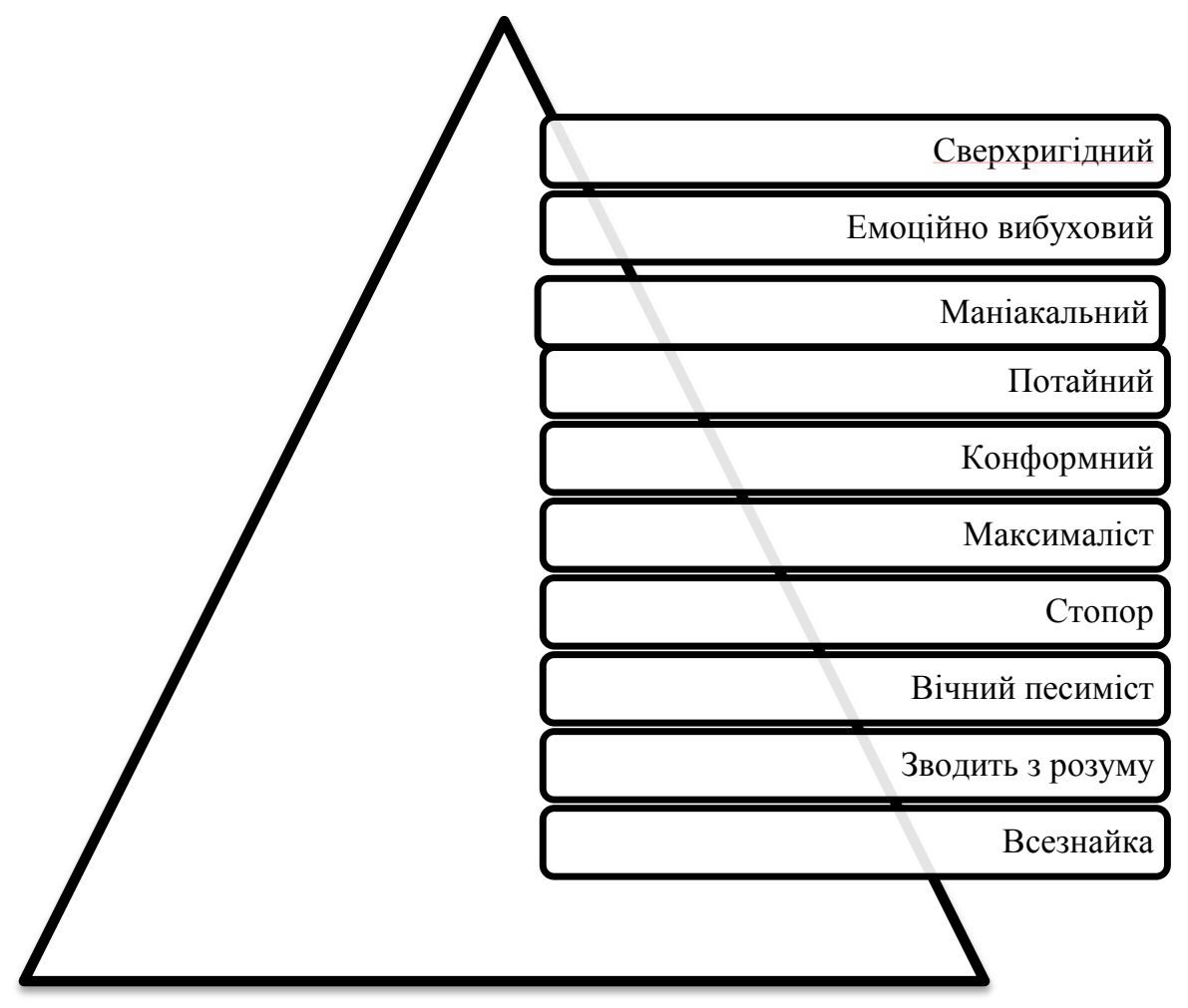

Рис. 2. Типи «важких» людей*

*систематизовано авторами на підставі джерел $[9,10,11]$

4. Надточний тип. У спілкуванні $з$ такими людьми краще не травмувати їх марно. Тим більше що вони і так часто страждають через свої дивацтва. Краще давати їм такі роботи, де вони зможуть проявити свою скрупульозність і відповідальність, тобто давати їм можливість використовувати свої недоліки 3 користю для спільної справи, а значить, підвищувати хоча б таким чином почуття їх власної значущості.

5. Безконфліктний тип. У спілкуванні з такими людьми рекомендація одна - побоюватися їх найбільшою мірою. Такі люди, в силу слабкості свого духу, здатні зрадити кого завгодно. Теоретично, звичайно, можна уявити, що ці люди в певних ситуаціях можуть проявити і волю, і принциповість, але для цього треба було б зачепити їх за щось «живе». Не кожному керівнику це доступно.

6. Цілеспрямовано конфліктний (раціональний) тип. Таких людей треба намагатися зробити своїми прихильниками і використовувати їх таланти в конструктивному руслі. Проблема для керівників підшукати для таких людей цікаві проблеми, де можна було б і ризикнути, і зобразити із себе стратега (або героя).

Загальні принципи спілкування з такими людьми пропонує Дж. Г. Скотт. Він вказує, що коли ми стикаємося 3 важкою в спілкуванні людиною, слід використовувати такий підхід, який відповідатиме конкретному характеру поведінки, але $\epsilon$ декілька універсальних принципів, якими ми можемо користуватися при вирішенні таких ситуацій:
1. Усвідомте, що людина важка в спілкуванні, і визначте, до якого типу людей вона належить.

2. Не попадіть під вплив цієї людини, ії точки зору, світогляд; зберігайте спокій і нейтралітет.

3. Якщо ви не хочете відхилитися від спілкування $з$ такою людиною, постарайтесь поговорити 3 нею і виявити причини її «важкості».

4. Намагайтеся знайти спосіб задоволення іiі прихованих потреб і інтересів.

5. Використовуйте сумісний підхід щодо вирішення конфліктів, що починають вимальовуватися після віднесення поведінки важкої людини до певного типу, іiї нейтралізації або взяття під контроль.

Сам же керівник не повинен бути конфліктною особистістю. Неприпустимо використовувати своє начальницьке положення для зняття внутрішньої напруги, виживання комплексу неповноцінності, задоволення хворобливого самолюбства [13].

Однак грамотний керівник повинен бути не тільки компетентним у професійній сфері, але й знати психологію своїх підлеглих. Дані знання забезпечать, по-перше, злагодженість в колективі, - адже психологічна несумісність часто являється причиною конфліктів серед працівників, - по-друге, допоможе уникнути більшість руйнівних конфліктних ситуацій саме $з$ перманентно-конфліктними особистостями.

Тож виведемо універсальний алгоритм вирішення трудових конфліктів (рис.3) [14]: 




\section{Рис. 3. Універсальний алгоритм вирішення трудових конфліктів * * авторська розробка}

Висновки та перспективи подальших досліджень. Раніше конфлікт найчастіше розглядався переважно ззовні, тобто з точки зору соціальної групи або конфліктної ситуації. Однак сьогодні все більш важливим стає не це, адже не кожен хоче і може слідувати методикам вирішення конфлікту. 3 кожним днем в суспільстві все більше з'являються так звані конфліктні особистості, які яскраво виділяються в групі. I перед психологією і конфліктологією стоїть завдання розібратися, що з себе представляють конфліктні особистості, які причини формування і чи можуть вони адаптуватися в суспільстві, а найголовніше: як взаємодіяти 3 ними оточуючим задля уникнення спалахів руйнівних конфліктів.

Отже, спираючись на давні та сучасні дослідження, ми з'ясували, що в основі конфліктогенності особистості можливо закладені комплекс неповноцінності, прихована агресія, фрустрація, недовіра до оточуючих, егоїзм - тобто внутрішні фактори людини.

Незважаючи на технологічний розвиток, направлений на максимальний комфорт для людства, на сьогоднішній день, як би це парадоксально не звуча- ло, існує «підступ всесвітнього благополуччя», як визначав у свої книзі А. В. Курпатов «5 рятівних кроків. Від депресії до радості» [15]. Зникла необхідність ворогувати за здобуття засобів виживання, але агресія лишилась.

Отже, у статті ми розглянули типологію конфліктних особистостей, в тому числі і «важких» людей в робочому колективі, визначили універсальні стратегії спілкування з ними та запропонували алгоритм вирішення трудових конфліктів. Знання щодо управління конфліктними працівниками особливо важливі для керівників, оскільки конфліктні особистості здатні навмисно й ненавмисно похитнути авторитет свого керівника під час чергової суперечки, внести розлад у взаємостосунках колективу, тим самим призвести до деструктивних наслідків, таких як, наприклад, зниження продуктивності праці. Керівники і працівники повинні приділяти значну увагу конфліктним проявам, вміти визначати конфліктогенні характеристики навіть на етапі підбору персоналу, оскільки конфліктогенні працівники негативно впливають на ефективності роботи колективу та в цілому підприємства.

\section{Література}

1. Центр соціальних та трудових досліджень. URL: https://www.facebook.com/socialandlaborresearch/ (дата звернення 21.01.2020р.)

2. Мир VUCA и подходы выживания в нем: веб-сайт. URL: http://becmology.ru/blog/management/vuca/htm(дата звернення 21.01.2020 p.)

3. Freud S. Civilization and its discontents. L. Internationaler Psychoanalytischer Verlag Wien, $1930.127 \mathrm{c}$.

4. Основы социально-психологической теории / Под ред. А. А. Бодалева и А. А. Сухова. М.: Международная педагогическая академия 1995. 4-43 с.

5. Бородкин Ф.М., Коряк Н.М. Внимание: конфликт! Новосибирск: Наука. 1989. 189 с.

6. Шейнов В. П. Управление конфликтами. СПб.: Питер.2014. 576 с. 
7. Скотт Д.Г. Конфликты. Пути их преодоления / Скотт Д. Г.; пер. с англ. К.: Внешторгиздат. 2000. 192 c. $172 \mathrm{c}$.

8. Брэмсон Р.М. Общение с трудными людьми / Брэмсон Р. М.; пер. с англ. К.: Внешторгиздат. 1991.

9. Спивак В. А. Корпоративная культура. СПб.: Питер. 2001. 352 с 2013. 505c.

10. Литвинюк А.А. Организационное поведение: учебник для бакалавров. М.: Издательство «Юрайт».

11. Смельяненко Л.М., Петюх В.М., Торгова Л.Н., Гриненко А.М. Конфліктологія: навч. посіб. К.: КНЕУ. 2003. 315c.

12. Крегер О., Тьюсон Дж. Типы людей и бізнес / Крегер О., Тьюсон Дж.; пер. с англ. М. Пантаев, М. М.: АСТ, Астрель. 1995. 560 с.

13. Берн Э. Игры, в которые играют люди: Психология человеческих взаимоотношений; Люди, которые играют в игры: Психология человеческой судьбы / Берн Э.; пер. с англ. А. Грузберг, М.: ФАИРПРЕСС. 2002. $480 \mathrm{c}$.

14. Козак К. Б. Конспект лекцій по конфліктології. Одеса: ОНАХТ. 2019. 165с.

15. Курпатов А.В. «5 спасительных шагов. От депрессии к радости»: «ApgadsMantojums». Рига: Нева. 2016. $160 \mathrm{c}$.

Стаття надійшла 27.01.2020

Стаття прийнята до друку 10.02.2020

Доступно в мережі Internet 31.03.20

Козак Е.Б.

кандидат экономических наук, доцент кафедра менеджмента и логистики E-mail: kozakkate.coach@gmail.com ORCID ID: 0000-0002-8099-6607
Корсикова Н.Н.

кандидат экономических наук, доцент кафедра менеджмента и логистики E-mail:nkorsikova@ukr.net ORCID ID: 0000-0002-1649-4725

Древова В.В.

студентка 4 курса фракультета менеджмента, маркетинга и логистики Одесская национальная академия пищевых технологий ул. Канатная, 112, г. Одесса, Украина, 65039

E-mail: prost0.vika1409@gmail.com

ORCID ID: 0000-0002-7278-5105

\section{ТИПОЛОГИЯ КОНФЛИКТНЫХ ЛИЧНОСТЕЙ И АЛГОРИТМ ВЗАИМОДЕЙСТВИЯ С НИМИ В РАБОЧЕМ ПРОЦЕССЕ}

У такого сложного френомена, каким является конфликт, есть множество источников, которые кроются в самой природы человека. Данная статья посвящена исследованию классификации конфрликтных личностей известными исследователями и стратегий общения с ними для предупреждения возникновения конфликтных ситуаций при управлении персоналом в рабочем процессе в целом. Типы конфллитных личностей следует разбить на две разновидности: ситуативно-конфликтные и перманентно-конфликтные. Для первого вида людей конфликтность - это не свойство характера, а реакция на конкретную ситуацию. Их готовность в отдельных случаях идти на конфликт вызывается отсутствием другого выхода из конфллитной ситуации. Вторая разновидность людей - индивиды, для которых конфрликтность - постоянное свойство их характера и поведения.

В статье освещены несколько удачных классификаций по разным ученым именно перманентно-конфликтных личностей и «тяжелых» людей в коллективе. Выявлены стратегии взаимодействия с ними, учитывая их поведенческие характеристики в соответствии каждого типа. Также мы уделили внимание такому важному фактору, как разница темперамента и характера личностей, что, несомненно, влияет на взаимодействие людей во время сотрудничества.

Рассмотрели общие рекомендации относительно поведения с основными типами конфликтных личностей в коллективе ради предупреждения конфликтных ситуаций. Данными знаниями стоит владеть, прежде всего, управленцам, ведь конфликтогенные личности встречаются в каждом коллективе. Но прежде всего, нужно уметь распознавать конфликтных и «тяжелых» людей еще на этапе подбора персонала. Ведь не секрет, что такие личности способны повлиять на рабочий процесс. 
В конце статьи сформирован универсальный простой алгоритм решения трудовых конфрликтов, следуя которому можно избежать разрушительных последствий деструктивных конфликтов в рабочем процессе.

Ключевые слова: конфликт, конфликтность, конфликтная ситуация, конфликтная личность, демонстративный тип, ригидный тип, неуправляемый тип, сверхточный тип, бесконфликтный тип, рациональный тип, «тяжелые» люди.

\section{Kozak K.}

Ph.D., Associate Professor

Department of Management and Logistics

E-mail: kozakkate.coach@gmail.com ORCID ID: 0000-0002-8099-6607
Korsikova $\mathbf{N}$.

Ph.D., Associate Professor

Department of Management and Logistics

E-mail:nkorsikova@ukr.net

ORCID ID: 0000-0002-1649-4725

Drevova V.

The student of the fourth grade of Management, Marketing and Logistics Faculty

Odessa National Academy of Food Technologies

Kanatna str., 112 Odesa, Ukraine, 65039

E-mail: prost0.vika1409@gmail.com

ORCID ID: 0000-0002-7278-5105

\section{TYPOLOGY OF CONFLICT PERSONALITIES AND ALGORITHM FOR INTERACTION WITH THEM IN THE WORKING PROCESS}

Such a complex phenomenon, which is a conflict, has many sources that lie in the very nature of man. This article is devoted to the study of the classification of conflicting personalities by famous researchers and strategies for communicating with them to prevent the occurrence of conflict situations in personnel management and the working process as a whole. Types of conflicting personalities should be divided into two varieties: situational-conflict and permanent-conflict. For the first kind of people, conflict is not a character trait, but a reaction to a specific situation. Their readiness in some cases to go to conflict is caused by the absence of another way out of the conflict situation. The second kind of people is individuals, for whom conflict is a constant property of their character and behavior.

The article is coves several successful classifications of namely permanent-conflict personalities and "heavy" people in the team by different scientists. Strategies for interacting with them, taking into account their behavioral characteristics in accordance with each type have been identified. We also paid attention to such an important factor as the difference in temperament and personality, which undoubtedly affects the interaction of people during cooperation.

The general recommendations regarding behavior with the main types of conflicting personalities in the team for the prevention of conflict situations have been considered. The knowledge of these tips should be owned primarily by managers, because conflict-prone individuals are found in every team. But first of all, you need to be able to recognize conflict and "heavy" people at the stage of recruiting. It is no secret that such individuals are able to turn the workflow for colleagues and even managers into hell.

At the end of the article, a universal algorithm for resolving labor conflicts has been formed, following which the destructive consequences of destructive conflicts in the work process can be avoided.

Key words: conflict, being conflict, conflict situation, conflict personality, demonstrative type, rigid type, uncontrollable type, ultra-precise type, conflict-free type, rational type, "heavy" people.

\section{References}

1. Tsentr sotsialnykh ta trudovykh doslidzhen. Retrieved January 21, 2020, from https://www.facebook.com/socialandlaborresearch/

2. Mir VUCA i podhodyi vyizhivaniya $\mathrm{v}$ nem. Retrieved January 21, 2020, from http://becmology.ru/blog/management/vuca/htm

3. Freud, S. (1930). Civilization and its discontents. Internationaler Psychoanalytischer Verlag Wien.

4. Bodaleva, A. A., \& Suhova, A. A. (Eds.). (1995). Osnovyi sotsialno-psihologicheskoy teorii. Moscow: Mezhdunarodnaya pedagogicheskaya akademiya.

5. Borodkin, F. M., \& Koryak, N. M. (1989). Vnimanie: konflikt! Novosibirsk: Nauka.

6. Sheynov, V. P. (2014). Upravlenie konfliktami. SPb.: Piter.

7. Skott, D. G. (2000). Konfliktyi. Puti ih preodoleniya. Kyiv: Vneshtorgizdat. 
8. Bremson, P. M. (1991). Obschenie s trudnyimi lyudmi. Kyiv: Vneshtorgizdat.

9. Spivak, V. A. (2001). Korporativnaya kultura. SPb.: Piter.

10. Litvinyuk, A. A. (2013). Organizatsionnoe povedenie. Moscow: Izdatelstvo «Yurayt».

KNEU.

11. Yemelianenko, L. M., Petiukh, V. M., Torhova, L. N., \& Hrynenko, A. M. (2003). Konfliktolohiia. Kyiv:

12. Kreger, O., \& Tyuson, Dzh. (1995). Tipyi lyudey i biznes. (M. Pantaev, Trans.). Moscow: AST, Astrel.

13. Bern, E. (2002). Igryi, v kotoryie igrayut lyudi: Psihologiya chelovecheskih vzaimootnosheniy; Lyudi, kotoryie igrayut v igryi: Psihologiya chelovecheskoy sudbyi. (A. Gruzberg, Trans.). Moscow: FAIRPRESS.

14. Kozak, K. B. (2019). Konspekt lektsii po konfliktolohii. Odesa.

15. Kurpatov, A. V. (2016). «5 Spasitelnyih shagov. Ot depressii k radosti»: «ApgadsMantojums». Riga: Neva.

Received 27 January 2020

Approved 10 February 2020

Available in Internet 31.03.2020

Цитування згідно ДСТУ 8302:2015

Козак К.Б., Корсікова Н.М., Древова В.В. Типологія конфліктних особистостей та алгоритм взаємодії з ними в робочому процесі // Економіка харчової промисловості. 2020. Т.12, вип. 1. С.45-54. doi: 10.15673/fie.v12i1.1668

Cite as APA style citation

Kozak, K., Korsikova, N., \& Drevova V. (2020). Typology of conflict personalities and algorithm for interaction with them in the working process. Food Industry Economics, 12(1), 45-54. doi: 10.15673/fie.v12i1.1668 